УДК 343.985

DOI https://doi.org/10.32837/pyuv.v0i2(31).590

\author{
О. В. Пчеліна \\ orcid.org/0000-0003-0224-1767 \\ доктор юридичних наук, доиент, \\ доцент кафедри кримінального процесу та організаиї досудового слідства \\ факультету № 1 \\ Харківського нащіонального університету внутрішніх справ
}

\title{
ОБСТАВИНИ, ЩО ПІДЛЯГАЮТЬ З'ЯСУВАННЮ ПІД ЧАС РОЗСЛІДУВАННЯ КРИМІНАЛЬНИХ ПРАВОПОРУШЕНЬ, І ЇХНЕ МІСЦЕ У СТРУКТУРІ ОКРЕМОЇ КРИМІНАЛІСТИЧНОЇ МЕТОДИКИ
}

Постановка проблеми. Побудова окремих криміналістичних методик повинна здійснюватися відповідно до їхньої внутрішньої структури [1, с. 132]. Питання про елементи, які повинні складати вказану структуру, досі залишається дискусійним. Із цього приводу немає уніфікованого підходу. Зокрема, жваві суперечки ведуться стосовно доцільності виокремлення такого елементу окремої криміналістичної методики, як обставини, що підлягають з'ясуванню, та його місця в цій структурі. Тому вирішення окресленої проблеми є актуальним питанням, яке потребує здійснення наукових пошуків у цьому напрямі.

Аналіз останніх досліджень і публікацій. Поняття, зміст і значення обставин, що підлягають з'ясуванню (встановленню, доказуванню), неодноразово досліджували у своїх працях такі вчені, як Р.С. Бєлкін, О.М. Васильєв, І.О. Возгрін, Л.Я. Драпкін, В.А. Журавель, Є.П. Іщенко, О.Н. Колесниченко, В.П. Колмаков, В.О. Образцова, М.О. Селіванова, Р.Л. Степанюка, С.Н. Чурилова, В.Ю. Шепітько, М.П. Яблоков та ін. Незважаючи на цінність напрацювань названих науковців, досі не вироблено єдиного підходу до визначення ролі та місця обставин, які підлягають з'ясуванню під час розслідування кримінальних правопорушень, у структурі методики розслідування злочинів окремого виду (групи). Як результат, відсутня уніфікована структура криміналістичної методики, що призводить до виникнення певних труднощів і суперечностей під час формування та реалізації окремих криміналістичних методик. У зв'язку із зазначеним метою представленої статті є висвітлення значення обставин, які підлягають з'ясуванню, а також з'ясування їх місця у структурі окремої криміналістичної методики.

Виклад основного матеріалу. Обставини, що підлягають з'ясуванню під час розслідування кримінальних правопорушень, відіграють важливу роль у діяльності з виявлення, розкриття та розслідування злочинів. Це пояснюється тим, що кримінальне провадження є програмою дій уповноважених суб'єктів, націлених на збирання достовірних, достатніх, допустимих і належних доказів. Йдеться про те, що доказування в рамках кримінального провадження здійснюється шляхом доказування низки обставин, які у своїй сукупності дозволяють встановити як наявність кримінального караного суспільно небезпечного діяння, так і наявність в ознаках скоєного діяння складу кримінального правопорушення; обрати вид і міру покарання; забезпечити відшкодування збитків, завданих злочином, та інших затрат, пов'язаних із провадженням досудового розслідування; поновити порушені кримінальним протиправним діянням права постраждалих осіб; попередити вчинення інших кримінальних правопорушень.

Тому цілком погоджуємося 3 думкою В.А. Журавля, згідно з якою обставини, що підлягають з'ясуванню, наповнюючись змістом конкретної кримінально-правової норми, трансформують їх у структуру, яка й утворює систему правових цілей і стратегічних завдань розслідування [2, с. 204]. Вони є результатом синтезу кримінально-процесуальних приписів щодо визначення предмета доказування у кримінальній справі, передбачених чинним законодавством, а також кримінально-правових ознак злочину певного різновиду [3, с. 13]. Ось чому В.О. Образцов пропонує в загальну методику розслідування включати положення, що містять інформацію про те, які обставини встановлюються в усіх випадках дослідження певних подій, розслідування тих видів діянь, що входять як елементи до відповідної криміналістично подібної групи, як організовується та здійснюється робота з їх виявлення та доказування, як потрібно діяти слідчому в умовах типових для цієї категорії справ ситуацій [4, с. 376-377].

Слушною також вважається позиція В.П. Колмакова, згідно з якою методика розслідування окремих видів злочинів, виходячи з положень кримінального закону, що визначає склад конкретного злочину, та кримінально-процесуального закону, котрий встановлює в загальних рисах межі доказування по справі, вказуе слідчому по кожному виду злочинів обставини, які підлягають з'ясуванню та повне, всебічне й об'єктивне дослідження яких приведе до встановлення об'єктивної істини по справі. Йдеться про суттєві обставини, питання, що підлягають з'ясуванню та до- 
слідженню по справі. Останні визначаються з меж доказування, які, у свою чергу, зумовлюються складом злочину та випливають із предмета доказування. До того ж, цілком доречними вбачаються тези про те, що не всі обставини рівнозначні за своїм характером і значенням для розслідування, проте всі вони тісно пов'язані між собою, оскільки з'ясування однієї обставини часто дозволяє 3'ясувати іншу чи інші обставини. Залежно від конкретної обстановки чергування з' ясування обставин може бути різним. Зокрема, в деяких випадках можуть включатися додаткові обставини, інколи вони можуть дещо видозмінюватися, доповнюватися [5, с. 12-13].

Тож важливе значення обставин, що підлягають з'ясуванню, для процесу розслідування злочинів є очевидним і беззаперечним. Оскільки визначення таких обставин надає розслідуванню злочинів цілеспрямованості, вказує на кінцеві цілі розслідування, правильну кримінально-правову кваліфікацію, визначення ознак, які пом' якшують і обтяжують кримінальну відповідальність або виключають їі, що дозволяє забезпечити реалізацію завдання повного, всебічного й об'єктивного дослідження обставин вчинення кримінальних правопорушень [6, с. 11]. Це дозволяє слідчому вирішувати кримінально-правові та кримінальні процесуальні завдання [7, с. 68]. Більше того, 3'ясування кола обставин, які підлягають встановленню, має суттєве значення для побудови методики розслідування злочинів, оскільки сприяє розв'язанню проблем криміналістичного характеру, зокрема дослідженню механізму й обстановки злочину, ролі кожного з його учасників, спрямованості слідчих версій, визначенню відповідних завдань розслідування [8, с. 30].

Не менш дискусійним досі лишається й питання про визначення місця обставин, що підлягають 3'ясуванню, у структурі окремої криміналістичної методики. Зокрема, аналіз наукової літератури вказує на те, що сформувалося декілька підходів до вирішення окресленої вище проблематики. Одна група вчених виділяє обставини, що підлягають з'ясуванню, як самостійний структурний елемент окремої криміналістичної методики (0.0. Алєксєєв, В.К. Весельський, Є.П. Іщенко, О.Н. Колесниченко, В.П. Колмаков, В.М. Малюга, В.О. Образцов, В.В. Пясковський, М.В. Салтевський, А.О. Топорков, А.В. Шмонін, М.Г. Шурухнов, Б.В. Щур та ін.), друга - включає їх до складу інших структурних елементів методики розслідування злочинів окремого виду (групи) (Ю.П. Аленін, Р.С. Бєлкін, О.М. Васильєв, С.І. Винокуров, І.О. Возгрін, І.І. Рубцов, В.Г. Танасевич, М.П. Яблоков). Деякі науковці поділяють думку про те, що криміналістична характеристика злочинів як елемент окремої криміналістичної методики органічно включає до свого складу перелік обставин, що підлягають встановленню (з'ясуванню). Тому не доцільно вносити згадані обставини до структури окремої методики (І.С. Андрєєв, І.Ф. Герасимов, Г.І. Грамович, Л.Я. Драпкін, М.І. Порубов).

Як приклад, I.I. Рубцов включає питання, які підлягають з'ясуванню при розслідуванні злочинів, поряд із вихідною інформацією про злочин, відомостями про спосіб вчинення злочинів і типові особистісні особливості злочинців і потерпілих, мотивами злочину, причинами й умовами, що сприяли вчиненню злочинів, до складу криміналістичної характеристики злочинів [9, с. 151-161]. Вказана позиція викликає певні заперечення, оскільки криміналістична характеристика й обставини, що підлягають 3' ясуванню, є різними за своїми суттю та призначенням категоріями [10, с. 285]. А саме - криміналістична характеристика вказує на коло обставин, які могли мати місце в дійсності, тобто визначає можливі варіанти вчинення злочинних дій, тоді як предмет доказування містить обставини, які слід встановити, визначаючи завдання розслідування $[11$, с. 8]. Іншими словами: обставини, що підлягають з'ясуванню, пов'язані з перспективною стороною структури криміналістичної методики, а саме з інформацією щодо побудови пізнавального процесу, спрямованого на формування необхідної доказової бази [3, с. 15-16].

В.О. Малярова з цього приводу вдало зазначає, що функціонально, методологічно і методично обставини, які підлягають з'ясуванню (встановленню), не можуть бути структурними компонентами криміналістичних характеристик, адже вони $\epsilon$ необхідними елементами доказування; для їх визначення не підходить загальна методологія побудови криміналістичної характеристики; вони виступають як пов'язуючий компонент між криміналістичними характеристиками (інформаційно-статистичними моделями) та діяльністю із розслідування злочину (у широкому розумінні) $[12$, с. $89 ; 13$, с. 174$]$.

Також зустрічаються думки вчених, що структура криміналістичної характеристики злочинів як елемент окремої криміналістичної методики відображає всі типові обставини, які необхідно встановити відповідно до уявлень про предмет доказування по цій категорії кримінальних справ. у зв'язку з цим завдання слідчого полягає у їхній конкретизації щодо специфіки злочину, що розслідується. Більше того, обставини, які підлягають встановленню, не виділяють як самостійний елемент методики розслідування злочинів окремого виду (групи), адже зазначені обставини відображаються в елементах криміналістичної характеристики злочинів та особливостях планування на початковому й наступному етапах розслідування, котрі, до речі, є самостійними елементами окремих криміналістичних методик [14, с. 692-694]. 
Висновки. Отже, обставини, які підлягають з'ясуванню, обов'язково повинні відобразитися у структурі окремої криміналістичної методики. Водночас вважається, що вказані обставини не повинні виокремлюватися. Вони повинні висвітлюватися поряд із типовими криміналістичними ситуаціями, тактичними завданнями, версіями, особливостями планування тощо в тій частині методики розслідування злочинів окремих видів (груп), де йдеться про особливості здійснення досудового розслідування на етапі збирання та перевірки інформації про злочин, початковому та наступному етапах [10, с. 286]. Тому пропонується в методиці розслідування злочинів окремого виду (групи) визначати обставини, що підлягають з'ясуванню, на кожному з етапів їх розслідування.

\section{Jimepamypa}

1. Щур Б.В. Теоретичні основи формування та застосування криміналістичних методик : монографія. Харків : Харків юридичний, 2010. $320 \mathrm{c}$.

2. Журавель В. Системи слідчих дій та тактичні операції в структурі окремої криміналістичної методики розслідування злочинів. Вісник Академії правових наук України. 2009. № 2 (57). С. 197-202.

3. Журавель В.А. Обставини, що підлягають 3'ясуванню, у структурі криміналістичної методики. Теорія та практика судової експертизи та криміналістики. Вип. 10. 2010. С. 12-20.

4. Образцов В.А. Криминалистика : учебник / под ред. В.А. Образцова. Москва : Юрид. лит., 1995. 592 с.

5. Колмаков В.П. Расследование убийств: лекции для студентов ВЮЗИ / под ред. Н.В. Терзиева. Москва, $1958.76 \mathrm{c.}$

6. Кириленко Н.Ю. Методика розслідування шахрайства у сфері побутових відносин : автореф. дис. ... канд. юрид. наук : 12.00.09. Одеса, 2013.20 c.

7. Тищенко В.В., Стрельцов Е.Л. Обстоятельства, подлежащие доказыванию по делам о корыстно-насильственных преступлениях. Криминалистика и судебная экспертиза.1995. Вып. 47. С. 67-72.

8. Тіщенко В.В. Концептуальні основи розслідування корисливо-насильницьких злочинів : автореф. дис. ... докт. юрид. наук : 12.00 .09 . Харьков, 2003. 51 с.

9. Рубцов И.И. Криминалистическая характеристика преступлений как элемент частных методик расследования : дисс. ... канд. юрид. наук : 12.00.09. Санкт-Петербург, 2001. 225 с.

10. Пчеліна О.В. Теоретичні засади формування та реалізації методики розслідування злочинів у сфеpi службової діяльності : дис. ... докт. юрид. наук : 12.00.09. Харків, 2017. 568 с.

11. Пчеліна О.В. Особливості предмета доказування у кримінальних справах про економічні злочини та ix вплив на методику розслідування : автореф. дис. ... канд. юрид. наук : 12.00.09. Харків, 2010. 23 c.

12. Малярова В.О. Обставини, що підлягають встановленню під час розслідування злочинів проти моральності у сфері статевих стосунків. Вісник Харківського національного університету внутрішніх справ. 2013. № 3 (62). C. 88-97.

13. Малярова В.О. Розслідування злочинів проти моральності у сфері статевих стосунків: теорія та практика : монографія / за ред. С.М. Гусарова. Харків : Диса плюс, 2013. 422 c.
14. Криминалистика : учебник / Т.В. Аверьянова, Р.С. Белкин, Ю.Г. Корухов, Е.Р. Россинская ; под ред. Р.С. Белкина. Москва : Норма, 2006. 992 с.

\section{Анотація}

Пчеліна О. В. Обставини, що підлягають з'ясуванню під час розслідування кримінальних правопорушень, $\mathrm{i}$ їхнє місце у структурі окремої криміналістичної методики. - Стаття.

У статті встановлено, що питання про включення обставин, які підлягають з'ясуванню під час розслідування кримінальних правопорушень, до структури окремої криміналістичної методики та визначення їх місця залишається дискусійним. Обставини, які підлягають з'ясуванню під час розслідування кримінальних правопорушень, відіграють важливу роль у діяльності 3 виявлення, розкриття та розслідування злочинів. Це пояснюється тим, що кримінальне провадження $\mathrm{e}$ програмою дій уповноважених суб'єктів, націлених на збирання достовірних, достатніх, допустимих і належних доказів. Наголошено, що визначення таких обставин надає розслідуванню злочинів цілеспрямованості. Встановлено, що сформувалося декілька підходів до вирішення питання про визначення місця обставин, які підлягають з'ясуванню, у структурі окремої криміналістичної методики. Одна група вчених виділяє обставини, що підлягають з'ясуванню, як самостійні структурні елементи окремої криміналістичної методики, друга - включає їх до складу інших структурних елементів методики розслідування злочинів окремого виду (групи). Деякі науковці розділяють думку про те, що криміналістична характеристика злочинів як елемент окремої криміналістичної методики органічно включає до свого складу перелік обставин, які підлягають встановленню (з'ясуванню), а отже, недоцільно вносити згадані обставини до структури окремої методики. Акцентовано увагу на необхідності включення обставин, що підлягають з'ясуванню під час розслідування кримінальних правопорушень, до структури криміналістичної методики. Запропоновано вказані обставини не виокремлювати як самостійний елемент окремої криміналістичної методики, а висвітлювати поряд із типовими криміналістичними ситуаціями, тактичними завданнями, версіями, особливостями планування тощо в тій частині методики розслідування злочинів окремих видів (груп), де йдеться про особливості здійснення досудового розслідування на етапі збирання та перевірки інформації про злочин, початковому та наступному етапах.

Ключові слова: обставини, що підлягають з'ясуванню, криміналістична методика, структура, розслідування кримінальних правопорушень, кримінальне провадження.

\section{Summary}

Pchelina O. V. Circumstances to be clarified during the investigation of criminal offenses and their place in the structure of a separate forensic methodology. Article.

In the article has been stated that the issue of including the circumstances to be clarified during the investigation of criminal offenses in the structure of a separate forensic methodology and determining their place remains debatable. It has been found that the circumstances to be clarified during the investigation of criminal offenses play an important and integral role in the activities of detection and investigation of crimes. This is due to the fact that criminal proceedings are a kind of program of 
action of authorized entities aimed at gathering reliable, sufficient, admissible and appropriate evidence. It has been emphasized that the definition of such circumstances gives purposefulness to the investigation of crimes. It has been established that several approaches to solving the issue of determining the place of circumstances to be clarified in the structure of a separate forensic methodology have been formed. One group of scientists identifies the circumstances to be clarified as an independent structural element of a separate forensic methodology, and the other - includes them in other structural elements of the methodology of investigation of crimes of a particular type (group). Some scholars share the view that the forensic characterization of crimes, as an element of a separate forensic methodology, organically includes a list of circumstances to be established (clarified), so it is not ap- propriate to include these circumstances in the structure of a separate methodology. Emphasis has been placed on the need to include the circumstances to be clarified in the investigation of criminal offenses in the structure of forensic methodology. It has been proposed not to single out these circumstances as an independent element of a separate forensic methodology, but to cover, along with typical forensic situations, tactical tasks, versions, planning features, etc. in the part of the methodology of investigation of crimes of certain types (groups), which deals with the features of pre-trial investigation at the stage of collecting and verifying information about the crime, initial and subsequent stages.

Key words: circumstances to be clarified, forensic methodology, structure, investigation of criminal offenses, criminal proceedings. 